\title{
THE
}

$11-1994$

\section{Survival Estimates for Snowy Plovers Breeding at Great Salt Lake, Utah}

Peter W. C. Paton

University of Rhode Island, ppaton@uri.edu

Follow this and additional works at: https://digitalcommons.uri.edu/nrs_facpubs

Terms of Use

All rights reserved under copyright.

\section{Citation/Publisher Attribution}

Peter W. C. Paton. (1994). Survival Estimates for Snowy Plovers Breeding at Great Salt Lake, Utah. The Condor, 96(4), 1106-1109. doi:10.2307/1369123

Available at: http://dx.doi.org/10.2307/1369123

This Article is brought to you for free and open access by the Natural Resources Science at DigitalCommons@URI. It has been accepted for inclusion in Natural Resources Science Faculty Publications by an authorized administrator of DigitalCommons@URI. For more information, please contact digitalcommons-group@uri.edu. 


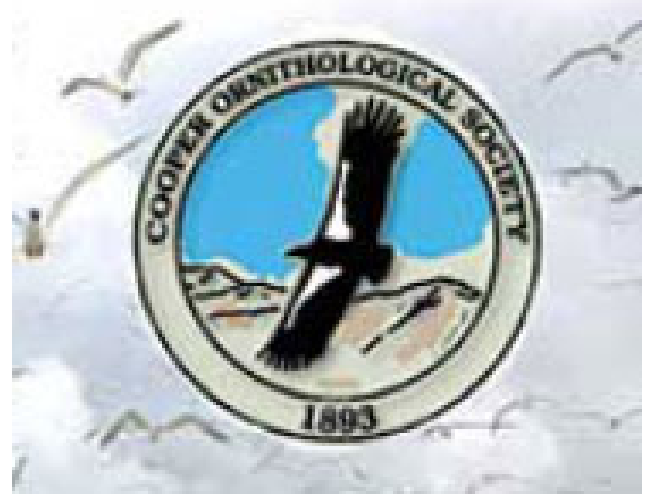

Survival Estimates for Snowy Plovers Breeding at Great Salt Lake, Utah Author(s): Peter W. C. Paton

Reviewed work(s):

Source: The Condor, Vol. 96, No. 4 (Nov., 1994), pp. 1106-1109

Published by: University of California Press on behalf of the Cooper Ornithological Society

Stable URL: http://www.jstor.org/stable/1369123

Accessed: 06/03/2013 15:00

Your use of the JSTOR archive indicates your acceptance of the Terms \& Conditions of Use, available at

http://www.jstor.org/page/info/about/policies/terms.jsp

JSTOR is a not-for-profit service that helps scholars, researchers, and students discover, use, and build upon a wide range of content in a trusted digital archive. We use information technology and tools to increase productivity and facilitate new forms of scholarship. For more information about JSTOR, please contact support@ jstor.org.

University of California Press and Cooper Ornithological Society are collaborating with JSTOR to digitize, preserve and extend access to The Condor. 
RaIkow, R. J. 1988. The analysis of evolutionary success. Syst. Zool. 37:76-79.

RaIkow, R. J. 1993. Structure and variation in the hindlimb musculature of the woodcreepers (Aves: Passeriformes: Dendrocolaptinae). Zool. J. Linn. Soc. 107:353-399.

RaIKow, R. J. 1994. A phylogeny of the woodcreepers (Dendrocolaptinae). Auk 111:104-114.

Raikow, R. J., A. H. Bledsoe, T. Syed, and A. G GLASGOW. 1993. Intraspecific variation in the hindlimb muscles of the Ivory-billed Woodcreeper and the Blue Jay, with a review of other species. Condor 95:497-506.

Reeve, H. K., AND P. W. Sherman. 1993. Adaptation and the goals of evolutionary research. Quart. Rev. Biol. 68:1-32.

RICHARDSON, F. 1942. Adaptive modifications for tree-trunk foraging in birds. Univ. Calif. Publ. Zool. 46:317-368.

SPRING, L. W. 1965. Climbing and pecking adapta- tions in some North American woodpeckers. Condor 67:457-488.

StOLPE, M. 1932. Physiologisch-anatomische Untersuchungen über die hintere Extremität der Vögel. J. Ornithol. 80:161-247.

STORER, R. W. 1971. Adaptive radiation of birds, p. 149-179. In D. S. Farner and J. R. King [eds.], Avian biology, vol. 1. Academic Press, New York.

SwOFFord, D. L. 1991. PAUP: phylogenetic analysis using parsimony, Version 3.0s. Computer program distributed by the Illinois Natural History Survey, Champaign, IL.

WeST-EBERHARD, M. J. 1992. Adaptation: current usages, p. 13-18. In E. F. Keller and E. A. Lloyd [eds.], Keywords in evolutionary biology. Harvard Univ. Press, Cambridge, MA.

WiNkLER, H., AND W. J. Bock. 1976. Analyse der Kräfteverhältnisse bei Klettervögeln. J. Ornithol. 117:397-418.

\title{
SURVIVAL ESTIMATES FOR SNOWY PLOVERS BREEDING AT GREAT SALT LAKE, UTAH ${ }^{\prime}$
}

\author{
Peter W. C. Paton \\ Utah Cooperative Fish and Wildlife Research Unit, Department of Fisheries and Wildlife Biology, \\ Utah State University, Logan UT 84322
}

Key words: Charadrius alexandrinus; Great Salt Lake; mark-recapture study; resighting probability; Snowy Plover; survival estimates.

Current knowledge of the breeding biology of Snowy Plovers (Charadrius alexandrinus) in North America is primarily confined to studies of their reproductive success (Boyd 1972; Page et al. 1983, 1985; Paton and Edwards 1990; Paton 1994), mating system (Boyd 1972, Warriner et al. 1986), dispersal (Stenzel et al., in press), and distribution (Page et al. 1991). Snowy Plover populations breeding along the Pacific Coast were recently listed as threatened by the U.S. Fish and Wildlife Service in April 1993 (Federal Register 1992), yet there are no quantitative survival estimates available for this species.

Page et al. (1983) and Warriner et al. (1986) calculated minimum annual survival estimates of 0.743 and 0.752 , respectively, based on the subsequent resightings of banded adult Snowy Plovers in coastal California. However, those rates probably underestimated actual annual survival rates because they were not based on capture-recapture models, such as a Jolly-Seber

\footnotetext{
' Received 5 April 1994. Accepted 26 July 1994.
}

modeling approach (Jolly 1965, Seber 1965). Jolly-Seber models use resightings to estimate survival probabilities for birds that were not resighted but were actually still alive. The purpose of this paper is to determine annual survival estimates for Snowy Plovers at Great Salt Lake, Utah, using a hierarchical modeling approach recently developed by Lebreton et al. (1992).

\section{METHODS}

The study was conducted at eight sites at Great Salt Lake, Utah, from 1990 to 1993: Locomotive Springs Waterfowl Management Area (WMA) $\left(41^{\circ} 41^{\prime} \mathrm{N}\right.$, $\left.112^{\circ} 55^{\prime} \mathrm{W}\right)$; Harold Crane WMA $\left(41^{\circ} 20^{\prime} \mathrm{N}, 112^{\circ} 08^{\prime} \mathrm{W}\right)$; the West Warren area of Harold Crane WMA $\left(41^{\circ} 18^{\prime} \mathrm{N}\right.$, $112^{\circ} 08^{\prime} \mathrm{W}$ ); the northwest corner of Ogden Bay WMA $\left(41^{\circ} 14^{\prime} \mathrm{N}, 112^{\circ} 14^{\prime} \mathrm{W}\right)$; Howard Slough WMA $\left(41^{\circ} 09^{\prime} \mathrm{N}\right.$, $\left.112^{\circ} 09^{\prime} \mathrm{W}\right)$, West Layton Marsh $\left(41^{\circ} 02^{\prime} \mathrm{N}, 112^{\circ} 05^{\prime} \mathrm{W}\right)$, Farmington Bay WMA $\left(40^{\circ} 55^{\prime} \mathrm{N}, 111^{\circ} 55^{\prime} \mathrm{W}\right)$ and $2 \mathrm{~km}$ northeast of Saltair Beach $\left(40^{\circ} 46^{\prime} \mathrm{N}, 11^{\circ} 08^{\prime} \mathrm{W}\right.$ ) (Paton 1994). Fieldwork was centered at two focal sites, Howard Slough WMA and West Layton marsh. Focal sites were surveyed 2-3 times per week from 1 April to 31 August, with one observer in 1990 and two observers from 1991 to 1993 . The other six sites were visited 14 times per month.

Incubating birds were trapped with a circular funnel trap (Lessells 1984); others were captured 0.1-1 km 
TABLE 1. Capture history matrix for Snowy Plovers at Great Salt Lake, Utah from 1990-1993.

\begin{tabular}{cccc}
\hline \hline Capture history & Adult males & Adult females & Immatures \\
\hline 1000 & 9 & 18 & 58 \\
1001 & 2 & 1 & 2 \\
1010 & 1 & 8 & 1 \\
1011 & 0 & 4 & 0 \\
1100 & 6 & 12 & 2 \\
1101 & 3 & 2 & 0 \\
1110 & 6 & 2 & 1 \\
1111 & 4 & 4 & 0 \\
0100 & 37 & 48 & 21 \\
0101 & 4 & 7 & 0 \\
0110 & 15 & 11 & 3 \\
0111 & 12 & 8 & 0 \\
0010 & 31 & 44 & 74 \\
0011 & 32 & 30 & 9 \\
\hline
\end{tabular}

a Capture or resighting $=1$, no capture or resighting $=0$.

away from nests by herding birds into two mist nets staked together to form a "V." Capture technique did not significantly affect resighting probabilities for females $(61 / 112$ caught on nests were subsequently resighted versus $12 / 25$ in mist nets $\left.\left[G^{2}=0.34, P=0.56\right]\right)$ or males $(42 / 60$ from nests were resighted versus 29 / 57 from nets $\left[G^{2}=3.52, P=0.061\right]$ ) (see Paton 1994). Adults were sexed based on plumage characteristics, whereas nestlings and juveniles (hereafter immatures) could not be sexed (Warriner et al. 1986). Plovers were individually marked with four color-bands, two on each tarsometatarsus (Page et al. 1983). Nestlings were banded with a single U.S. Fish and Wildlife Service (USFWS) band, with two narrow strips of automobile pin-striping tape unique for each brood soldered over the band. Fledglings had a USFWS band plus one color-band.

\section{MARK-RECAPTURE ANALYSIS}

I used a Jolly-Seber modeling approach (Jolly 1965, Seber 1965) following methodology outlined in Lebre-
TABLE 3. Annual survival and resighting probabilities for Snowy Plovers at Great Salt Lake. Parameter estimates were based on the most parsimonious JollySeber model, which found that survival rates were timedependent and resighting probabilities were sex-specific (see Table 2).

\begin{tabular}{|c|c|c|c|c|}
\hline Age/sex & Years & Estimate & SE & $95 \%$ CI \\
\hline \multicolumn{5}{|l|}{ Survival rates } \\
\hline Adults & $\begin{array}{r}1990- \\
1991\end{array}$ & 0.880 & 0.076 & $0.640-0.968$ \\
\hline Adults & $\begin{array}{r}1991- \\
1992\end{array}$ & 0.578 & 0.050 & $0.478-0.672$ \\
\hline Adults & $\begin{array}{r}1992- \\
1993\end{array}$ & 0.732 & 0.071 & $0.573-0.848$ \\
\hline Immatures & pooled & 0.385 & 0.304 & $0.048-0.885$ \\
\hline \multicolumn{5}{|l|}{ Resighting rates } \\
\hline $\begin{array}{l}\text { Adult males } \\
\text { Adult females } \\
\text { Immatures }\end{array}$ & $\begin{array}{l}\text { pooled } \\
\text { s pooled } \\
\text { pooled }\end{array}$ & $\begin{array}{l}0.675 \\
0.518 \\
0.213\end{array}$ & $\begin{array}{l}0.061 \\
0.050 \\
0.171\end{array}$ & $\begin{array}{l}0.547-0.781 \\
0.420-0.615 \\
0.036-0: 666\end{array}$ \\
\hline
\end{tabular}

ton et al. (1992) to calculate annual survival estimates. I first performed a goodness-of-fit test for the initial model, $S_{1}, P_{1}$ (i.e., survival $(S)$ rates and resighting $(P)$ were both time ( $t$ ) dependent), using Tests 2 and 3 from Program RELEASE (Burnham et al. 1987). I assumed that resightings were equivalent to recaptures. These two tests examined the assumptions that birds released on different occasions had equivalent survival and resighting probabilities and whether or not sparse data could be pooled for further analyses (see Burnham et al. 1987, Lebreton et al. 1992 for further details). I then used Program SURGE (Lebreton et al. 1992) for model fitting and calculating likelihood ratio tests. Model selection was based on Akaike's Information Criterion (AIC), which was calculated from the maximum loglikelihood plus the model's number of estimable parameters. The model with the lowest AIC was then selected as the best fitting CJS model, because AIC provides an unbiased criterion for model selection (Le-

TABLE 2. Potential annual survival rate models for adult Snowy Plovers at Great Salt Lake.

\begin{tabular}{|c|c|c|c|c|}
\hline Model $^{2}$ & $n p^{b}$ & $-2 \ln L^{c}$ & $\mathbf{A I C}^{\mathbf{d}}$ & Comparison \\
\hline $\mathbf{S}, \mathbf{P}$ & 2 & 815.62 & 819.62 & Constant $\mathbf{S}$ and $\mathbf{P}$ \\
\hline $\mathbf{S}_{\mathrm{s}}, \mathbf{P}$ & 3 & 813.64 & 819.64 & Sex differences in $S$, constant $P$ \\
\hline $\mathbf{S}, \mathbf{P}_{\mathbf{s}}$ & 3 & 809.74 & 815.74 & Constant $S$, time effect on $P$ \\
\hline $\mathbf{S}_{\mathbf{s}}, \mathbf{P}_{\mathbf{s}}$ & 4 & 809.44 & 817.44 & Sex differences in $\mathbf{S}$ and $\mathbf{P}$ \\
\hline$S_{t}, P$ & 4 & 805.04 & 813.04 & Time effect on $S$, constant $P$ \\
\hline$S_{t}, P_{s}$ & 5 & 798.96 & 808.96 & Time effect on $\mathbf{S}$, sex differences in $\mathbf{P}$ \\
\hline $\mathbf{S}_{\mathrm{s}}, \mathbf{P}_{\mathrm{t}}$ & 5 & 812.86 & 822.86 & Sex difference in $S$, time effect on $P$ \\
\hline$S, P_{s \times t}$ & 7 & 807.04 & 821.04 & Constant $\mathbf{S}$, time/sex interaction on $\mathbf{P}$ \\
\hline$S_{t}, P_{s \times t}$ & 8 & 796.96 & 812.96 & Time effect on $\mathrm{S}$, time/sex interaction on $\mathbf{P}$ \\
\hline$S_{s}, P_{s \times t}$ & 8 & 807.03 & 823.03 & Sex differences in $\mathrm{S}$, time/sex interaction on $\mathrm{P}$ \\
\hline
\end{tabular}

a Model notation: $S=$ survival probability, $P=$ resighting probability, $s=\operatorname{sex}, t=$ time, $x=$ interaction term.

' Number of estimable parameters.

c $L=$ likelihood function.
d Akaike's Information Criterion $=2 n p+-2 \ln L$. 
breton et al. 1992). Potential survival models examined included 13 combinations of sex, time, and sex by time interaction terms for survival probabilities (S) and resighting probabilities (P). Annual survival estimates were calculated separately for immatures $(<1$ year old) and adults ( $\geq 1$ year old).

\section{RESULTS}

I used the capture history data for 532 Snowy Plovers (162 adult males, 199 adult females, and 171 immature plovers) to determine annual survival (S) and resighting $(\mathrm{P})$ probabilities for birds breeding in northern Utah (Table 1). The goodness-of-fit test for the Jolly-Seber model $\left(\mathbf{S}_{t}, \mathbf{P}_{t}\right)$ (i.e., survival and resighting probabilities were time-dependent) was not rejected (Program RELEASE Test $2+$ Test 3 [Burnham et al. 1987]: $\chi^{2}=$ $11.4, P=0.18$ ). Therefore, the data were appropriate for a Jolly-Seber modeling approach based on the goodness-of-fit test results.

Of the 13 survival models tested, one model $\left(S_{t}, P_{s}\right)$ clearly had the smallest AIC (Table 2). This model postulated that survival rates were time-dependent and resighting rates were sex-specific. Based on this model, survival rates tended to be relatively high during the winters 1990-1991 and 1992-1993, and low in the winter of 1991-1992 (Table 3). The best estimate for the average annual survival probability for an adult plover, 0.687 , was determined using the Jolly-Seber model $\left(S, P_{s}\right.$; i.e., a model with constant survival and sex-specific resighting probabilities).

Males had a significantly higher probability of being resighted than females (Table 3). Given this mean overall survival estimate, mean life expectancy for an adult plover (i.e., $\geq 1$ year old; Warriner et al. 1986) was 2.7 years. Few resightings of immature plovers resulted in imprecise survival estimates, resulting in large confidence intervals around the mean survival estimate of 0.385 (Table 3 ).

\section{DISCUSSION}

Snowy Plovers breeding at Great Salt Lake are migratory and winter around the Gulf of California and the west coast of Baja California (G. Page, M. Stern, and P. Paton, unpubl. data). The mean survival estimate I calculated for adult plovers in northern Utah $(0.687)$ was lower than a minimum survival estimate for a population of Snowy Plovers consisting of both migratory and resident individuals in coastal California (0.752; Warriner et al. 1986). However, annual variation in survival estimates at Great Salt Lake (0.5780.880; Table 3) encompassed the coastal California estimate. The average survival estimate for Snowy Plovers at Great Salk Lake was similar to a Jolly-Seber survival estimate for a migratory population of Piping Plovers (Charadrius melodus) nesting in North Dakota (0.664; Root et al. 1992).

Root et al. (1992) found that annual survival probabilities for Piping Plovers fluctuated somewhat dramatically between years, although there was not significant annual variation due to large confidence intervals around yearly estimates. I also found that survival probabilities varied annually, but I could not differentiate between permanent emigration and increased mortality. It is possible that the low survival estimates for the winter of 1991-1992 were due to permanent emigration from Great Salt Lake, rather than higher mortality rates. Therefore, if permanent emigration was a relatively common event for Snowy Plovers at Great Salt Lake, then the survival estimates presented here underestimate true survival rates. Given the long-distance intra- and inter-year movements patterns documented for this species (Stenzel et al., in press), it is quite possible that permanent emigration is a likely event for plovers breeding at Great Salt Lake.

There were not enough resightings of immature plovers (both nestlings and fledglings) at Great Salt Lake to accurately estimate survival for that cohort. The only other published juvenile survival estimate comes from Page et al. (1983), who subsequently resighted 9 of $14(64.3 \%)$ fledglings banded in coastal California. The estimate by Page et al. (1983) was based on fledglings; therefore, it was higher than the survival estimate that I calculated for immature plovers (i.e., both chicks and fledglings combined) in Utah. However, survival estimates for immature plovers were lower in California than Utah. Page et al. (1983) estimated a fledging rate of 0.546 chicks per successful brood at Mono Lake, with $50 \%$ of raising $\geq 1$ chick. Therefore, a crude estimate for immature survival rates for California plovers would be $0.175(0.5 \times 0.643 \times 0.546)$ versus 0.385 for this study. Because variations in immature survival estimates can have dramatic impacts on estimates of the finite rate of population change, it would be helpful to gather more data to obtain a better estimate of immature Snowy Plovers survival rates in western North America.

As with Piping Plovers in the Great Plains (Root et al. 1992, Ryan et al. 1993), little is known about mortality factors for immature and adult Snowy Plovers at Great Salt Lake. I only observed a source of juvenile mortality once, when an American Kestrel (Falco sparverius) captured a two-week old chick. Red foxes (Vulpes vulpes) and Northern Harriers (Circus cyaneus) were other common, potential predators for juveniles in northern Utah (Paton, pers. observ.). In addition, Peregrine Falcons (Falco peregrinus) have been re-introduced to northern Utah by the Division of Wildlife, using a series of 10 hack towers around Great Salt Lake. The remains of several adult Snowy Plovers have been found at the base of these towers (Don Paul, Utah Division of Wildlife Resources, pers. comm.). Obviously, much more needs to be learned about the factors affecting Snowy Plover survival rates, especially in light of their recent listing as a threatened species.

Financial support for this project was provided by the Native Wildlife Section of the Utah Division of Wildlife Resources. Jennifer Levy, Jack Dalton, and Craig Kneedy helped with the fieldwork. Thomas C. Edwards Jr. helped with statistical and editorial advice. I thank Frank Messina, Mark Ritchie, Kim Sullivan, John Kadlec, and two anonymous reviewers for provided useful suggestions to help improve the manuscript. Finally, I thank David R. Anderson for providing invaluable help with the survival analyses using program SURGE. 


\section{LITERATURE CITED}

BoyD, R. I. 1972. Breeding biology of the Snowy Plover at Cheyenne Bottoms Waterfowl Management Area, Barton County, Kansas. M.Sc.thesis Kansas State Teachers College, Emporia, KS.

Burnham, K. P., D. R. Anderson, G. C. White, C. BrownIE, AND K. H. Pollock. 1987. Design and analysis methods for fish survival experiments based on release-recapture. Am. Fish. Soc. Monogr. 5, Bethesda, MD.

Federal Register. 1992. Endangered and threatened wildlife and plants: determination of threatened status for the Pacific coast population of the western Snowy Plover. Federal Register 58:12864 12874.

Jolly, G. M. 1965. Explicit estimates from capturerecapture data with both death and immigrationstochastic model. Biometrika 52:225-247.

Lessells, C. M. 1984. The mating system of Kentish Plovers Charadrius alexandrinus. Ibis 126:474 483.

$\rightarrow$ Lebreton, J.-D., K. P. Burnham, J. Clobert, ANd D. R. ANDERSON. 1992. Modeling survival and test ing biological hyptheses using marked animals: a unified approach with case studies. Ecol. Mono. 62:67-118.

$\rightarrow$ Page, G. W., L. E. Stenzel, And C. A. Ribic. 1985. Nest site selection and clutch predation in the Snowy Plover. Auk 102:347-353. $\rightarrow$ Page, G. W., L. E. Stenzel, D. W. Winkler, and C. W. Swarth. 1983. Spacing out at Mono Lake: breeding success, nest density, and predation in the Snowy Plover. Auk 100:13-24.

Page, G. W., L. E. Stenzel, W. D. Shuford, and C. R. BRUCE. 1991. Distribution and abundance of the Snowy Plover on its western North American breeding grounds. J. Field Ornithol. 62:245-255.

Paton, P.W.C., AND T. C. EDwards, JR. 1990. Status and nesting ecology of the Snowy Plover at Great Salt Lake-1990. Utah Birds 6:49-66.

Paton, P.W.C. 1994. Breeding biology of the Snowy Plover at Great Salt Lake, Utah. Ph.D.diss., Utah State Univ., Logan, UT.

Root, B. G., M. R. Ryan, AND P. M. MaYer. 1992. Piping Plover survival in the Great Plains. J. Field Ornithol. 63:10-15.

SEBER, G.A.F. 1965. A note on the multiple capture census. Biometrika 52:249-259.

Stenzel, L. E., J. C. Warriner, J. S. WARriner, K. S. Wilson, F. C. Bistrup, and G. W. Page. In press. Long-distance breeding dispersal of Snowy Plovers in western North America. J. Anim. Ecol.

Warriner, J. S., J. C. Warriner, G. W. Page, and L. E. STENZEL. 1986. Mating system and reproductive success of a small population of polygamous Snowy Plovers. Wilson Bull. 98:15-37.

\title{
THE SPUR-WINGED PLOVER (VANELLUS SPINOSUS) IS A DETERMINATE EGG LAYER'
}

\author{
AkIva Yogev and Yoram Yom-Tov \\ Department of Zoology, Tel Aviv University, Tel Aviv 69978, Israel
}

Key words: Spur-winged Plover; Vanellus spinosus; Charadriidae; determinate layer.

Birds can be categorized according to whether their clutch size can be altered by addition or removal of eggs during laying (indeterminate and determinate egg layers, respectively; Cole 1917, Kennedy 1991). We report a series of experiments that describes the Spurwinged Plover (Vanellus spinosus) as a determinate layer.

The Spur-winged Plover is the most abundant resident plover in Israel, where it resides throughout the Mediterranean region of the country. This species is

\footnotetext{
' Received 12 April 1994. Accepted 28 July 1994.
}

monogamic, and both members of the pair take equal share in nesting activities. Eggs are laid in a shallow depression in the ground, surrounded by small stones which the parents bring during the incubation period. Like most temperate zone Charadrii, most $(60 \%)$ clutches of this species have four eggs (mean 3.4; SD $=0.84 ; n=632$ ), laid at about two day intervals (Yogev 1993). A population of this species was studied in kibbutz Giv' at Hayyim $\left(32^{\circ} 23^{\prime} \mathrm{N}, 34^{\circ} 55^{\prime} \mathrm{E}\right)$ during the breeding seasons (March-September) of 1989-1992, and experiments to determine whether the Spur-winged Plover is a determinate or indeterminate egg layer were conducted during 1990. One egg per nest was added or removed after the second, third, or fourth egg was laid in a nest, either on the day of laying or on the next day. The added eggs were taken from other nests in the vicinity. Although Kennedy (1991) and Haywood 